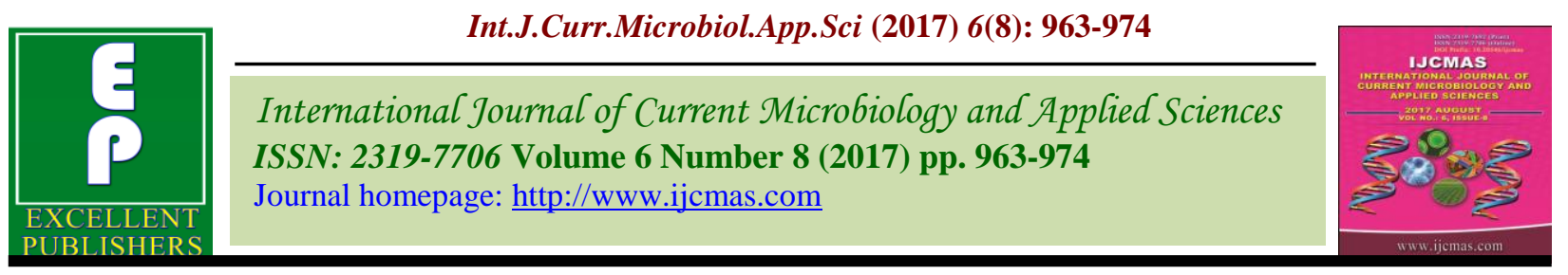

Original Research Article

https://doi.org/10.20546/ijcmas.2017.608.118

\title{
Standardization of Gluten Free Chickpea Flour Based Cake Mix by Using Response Surface Methodology
}

\author{
Thirukkumar Subramani*, Hemalatha Ganapathyswamy \\ and Senthamaraiselvi Lakshmanan
}
Department of Food Science and Nutrition, Home Science College and Research Institute, Tamilnadu Agricultural University, Madurai - 625104, Tamil Nadu, India
*Corresponding author

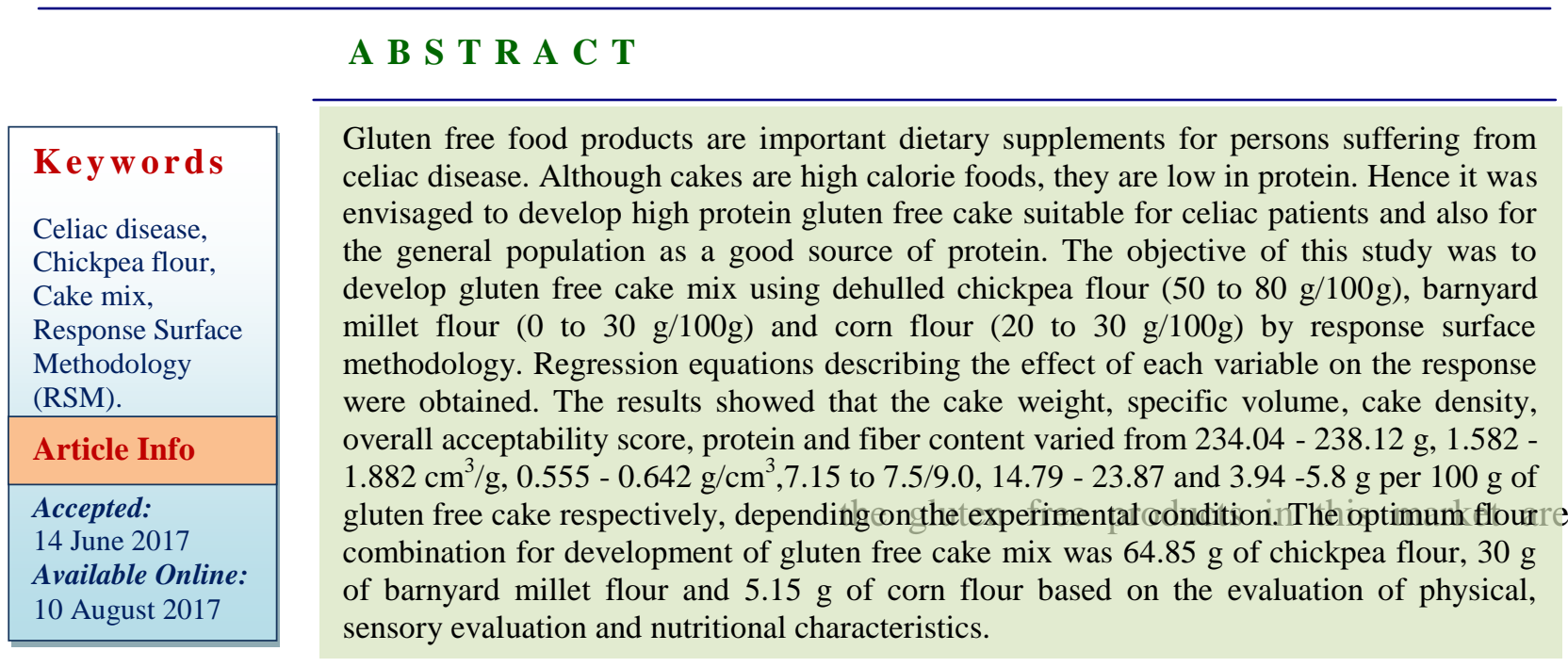

\section{Introduction}

Celiac Disease (CD) is associated with intolerance to the intake of foods containing gluten and causes damage to the surface of the intestinal mucosa, which leads to an inability to use nutrients (Valentina et al., 2010). The main agents responsible for celiac disease are gluten proteins from wheat and similar proteins in other closely related cereals such as barley, rye and oats (Kasarda, 2001; Kathrin et al., 2017).

Celiac disease is a specific disorder which affects intestinal absorption of nutrients and the only treatment is a strict adherence to a gluten free diet (Boye et al., 2010). Most of starch based with the addition of different types of hydrocolloids. Also, the gluten free formulations contain gums as gluten replacements and generally lack in dietary fibers and other essential nutrients (Sadaf et al., 2016). Therefore it is very important to develop gluten free foods with high nutritional value. The addition of legumes and pulses to other cereal-based products could be a good alternative for increasing the protein value with the added advantage of the supplementary value of cereal and pulse proteins. 
Among the commonly consumed pulses, chickpea (Cicer arietinum) is an important source of protein, carbohydrate and minerals, particularly to the population groups of developing nations. Chickpea contains $21.1 \mathrm{~g}$ protein, $3.1 \mathrm{~g}$ fat, $53.4 \mathrm{~g}$ carbohydrate, $11.1 \mathrm{~g}$ fiber and $5.9 \mathrm{~g}$ ash, $360 \mathrm{mg}-\mathrm{Ca}, 315 \mathrm{mg}-\mathrm{P}$, $8.2 \mathrm{mg}$ - Fe, $5.4 \mathrm{mg}-\mathrm{Zn}, 5.4 \mathrm{mg}-\mathrm{Mn}, 1.1$ $\mathrm{mg}-\mathrm{Cu}$ and 490 - kcal per $100 \mathrm{~g}$ (Dimitrios, 2006, Khan et al., 2010).

Chickpea presents good balance of amino acids, relatively low levels of antinutritional factors and better bioavailability of proteins. Major carbohydrate portion of chickpea is starch that represents nearly $83.9 \%$ of the total carbohydrate (El-Adawy, 2002) and is also rich in vitamins and minerals (Wood and Grusak, 2007). Pulses also provide a wide range of phytochemicals including antioxidants and phytosterols which are beneficial to health.

The use of cereals/leguminous blend may be nutritionally convenient in cake manufacturing. The use of pulses/non wheat flour as an alternate for wheat flour may affect the viscoelastic properties of normal wheat flour dough. This could be compensated by addition of viscoelastic property compounds in gluten free products in order to improve nutritional quality, structure, mouth feel, acceptability and shelf life (Korus et al., 2006).

Sabanis et al., (2006) noticed that, gluten free dough with chickpea flour presented protein contents that ranged between 13.0 and 18.36 $\%$. While, Duranti (2006) reported that the protein level in chickpea added to gluten free dough might be considered as nutraceutical properties attributed to legume proteins.

Response surface methodology (RSM) which involves design of experiments, selection of levels of variables in experimental designs, fitting mathematical models and finally selecting variables levels by optimizing the response was employed in the study (Nithya et al., 2016). Using Design Expert software, RSM can be performed for optimization of product ingredients. Along with optimization, RSM was also used to find the effect of correlation between the inputs on the response. Wherein more than one response can be studied (Josephine et al., 2014).

The objective of the present work was aimed at developing gluten free eggless ready to bake cake mix from chickpea, barnyard millet and corn flour. Therefore, this study was undertaken to investigate the relationship and interaction between the quantity of raw ingredients and its impact on the physical, sensory and nutritional characteristics of the product.

\section{Materials and Methods}

The commercially available chickpea flour $(\mathrm{CPF})$; barnyard millet flour (BF) and corn flour $(\mathrm{CF})$ and other ingredients were obtained from local market of Madurai, Tamil Nadu. Xanthan gum as gluten replacer was (M/s. Jan Enterprises, Chennai) used in the formulation of gluten free cake mix. All the dry ingredients were mixed and sieved in a BS 60 mesh without addition of water and refined oil. The known weight of each cake mix $(300 \mathrm{~g})$ was packed in air tight polyethylene pouch and stored in room condition $\left(30 \pm 2^{\circ} \mathrm{C}\right)$ for development of cake and for further studies.

\section{Preparation of cake from cake mix}

The cake was prepared as per the single-bowl mixing procedure. All ingredients were mixed at speed 6 using a cake blender for duration of $10 \mathrm{~min}$. The cake dough was developed from cake mix with addition of $120 \mathrm{ml}$ of drinking water and it was blended at speed 6 using a 
kitchen level professional mixer per $150 \mathrm{~g}$ of cake mix. After blending, $25 \mathrm{ml}$ of refined oil was added into the blended mix and further blended for 2 minutes. Known quantity of the weighed dough was poured into the greased aluminum baking pans $(15 \times 7.5 \times 7.5 \mathrm{~cm})$ and baked. Baking for each sample was conducted in a laboratory baking oven with air circulation at $180^{\circ} \mathrm{C}$ for $30 \mathrm{~min}$. The loaves were removed from the pans, cooled at room temperature and packed.

\section{Physical characteristics}

The weight of the gluten free cake samples were weighed before and after baking by using Avery Balance having a capacity of 2 $\mathrm{kg}$ (AACC method, 2000).

The specific volume $\left(\mathrm{cm}^{3} / \mathrm{g}\right)$ of the cake was determined as the ratio of the loaf volume (seed displacement method described by Wang et al., 2002) of cake to the weight of the cake. Cake density was determined by dividing the weight of cake with loaf volume of cake (Shogren et al., 2003).

\section{Sensory characteristic}

\section{Overall acceptability}

The developed cake samples were subjected to sensory evaluation using a panel of fifteen semi trained judges for accessing overall acceptability sensory scores on a hedonic score scale of nine points $(1=$ disliked extremely, 9 = liked extremely). Each taster received one slice of cake as well as a tray containing the coded samples with two digits number (Amerine et al., 1965).

\section{Nutritional characteristics}

The gluten free cake was analyzed for protein and fiber as per the standard approved methods of AACC (2000). Crude protein was determined by the Micro Kjeldahl method using 6.25 as the conversion factor. Crude fiber was determined by acid hydrolysis was determined by Soxhlet extraction method.

\section{Experimental design}

In designing this experiment by response surface methodology (RSM), a central composite design was employed. D - Optimal Design (DOD) which was used to study the interaction of process variables by applying RSM (Bezerra, 2008).

The simultaneous effects of independent variables were $\mathrm{X}_{1}$ - CPF (50 to $80 \mathrm{~g} / 100 \mathrm{~g}$ ), $\mathrm{X}_{2}$ -BMF (0 to $30 \mathrm{~g} / 100 \mathrm{~g}$ ) and $\mathrm{X}_{3}-\mathrm{CF}$ (20 to $30 \mathrm{~g} / 100 \mathrm{~g})$. The cake ingredients were blended according to the experiment run with addition of fixed quantity level of other ingredients viz., skim milk powder - $10 \mathrm{~g}$, icing sugar - 50 $\mathrm{g}$, xanthan gum - $1.5 \mathrm{~g}$ and sodium bi carbonate - $1.5 \mathrm{~g}$ per $100 \mathrm{~g}$ of each blended cake flour respectively.

Six dependent variables were selected as responses for representing the main parameters of cake quality namely physical characteristics (weight, specific volume and cake density), sensory characteristics in term of overall acceptability (OAA) score and nutrient content which include protein and fiber. The Design Expert 6.0.8 software was used to generate the special cubic model that fit the experimental data, to draw the response surface plots and optimize $\mathrm{CPF}, \mathrm{BF}$ and $\mathrm{CF}$.

Five levels of each variable were chosen and twelve baking trials were performed for the evaluation of the optimized formulation. Three replicates at the center of the design were used to allow for estimation of the pure error at sum of the square.

The interaction design for independent variables and responses are presented in table 
1. The experimental data for each response variable was fitted to the special cubic model. The regression parameters for the equations were calculated based on model. Analysis of Variance (ANOVA) was performed to obtain the coefficients of the final equation for better accuracy. Three-dimensional surface plots were drawn to illustrate the interactive effects of independent variables on the single dependent variable, while keeping constant the other variables. All variables of the polynomial regression at a significance level of $\mathrm{p}<0.05$ were included in the model, and the coefficient of determination $\left(\mathrm{R}^{2}\right)$ was generated in order to assess the special cubic model (Table 2).

The response surfaces were generated from the equation of the second order polynomial, using the values of each independent variable to the maximum quadratic and linear response. For the best fit of response surface models, $\mathrm{R}^{2}$ should be at $\geq 0.80$. The $\mathrm{R}^{2}$ values for these responses were more than 0.80 , representing that the regression models fitted excellently. Sin et al., (2006) also suggested that the $\mathrm{R}^{2}>0.80$ for a good fit of response model.

\section{Results and Discussion}

The interaction between the independent variables and its responses as noted in table 1 were recorded. The values of cake weight, specific volume, cake density, overall acceptability score, protein and fiber content varied from $234.04-238.12 \mathrm{~g}, 1.582$ - 1.882 $\mathrm{cm}^{3} / \mathrm{g}, 0.555-0.642 \mathrm{~g} / \mathrm{cm}^{3}, 7.15$ to $7.5 / 9.0$, 14.79 - 23.87 and $3.94-5.8 \mathrm{~g}$ per $100 \mathrm{~g}$ of gluten free cake respectively.

\section{Response surface plots}

\section{Effect of independent variables on cake weight}

The relationship between the independent variable and cake weight is presented in equation - 1 and figure 1. Analysis of variance for each response revealed significant difference $(\mathrm{P}<0.05)$ for cake weight, with regard to $\mathrm{CPF}, \mathrm{BF}$ and $\mathrm{CF}$.

In the present study, the special cubic design was attributed with the independent variables and cake weight. The adjustment of the second order to the weight of cake indicated that corn flour is the variable that most influenced these characteristics.

According to Equation - 1, it can be observed that the binary system of chickpea flour $\mathrm{x}$ barnyard millet flour exerted positive influence for increase in cake weight, whereas the binary system of chickpea flour $\mathrm{x}$ maize flour and barnyard millet flour $\mathrm{x}$ corn flour showed an antagonistic effect and reduced weight of the cake.

Cake weight $=25.89+234.05 \mathrm{X}_{1}+242.65 \mathrm{X}_{2}$ $+234.95 X_{3}+6.11 X_{1} X_{2}-0.23 X_{1} X_{3}-0.16$ $\mathrm{X}_{2} \mathrm{X}_{3}+6.58 \mathrm{X}_{1} \mathrm{X}_{2} \mathrm{X}_{3}\left(\mathrm{R}^{2}=0.99 \ldots \ldots\right)$

The combination of highest level of chickpea flour, medium level of millet flour and without addition of corn flour levels of three independent factors resulted in increasing the weight of the cake.

Addition of the above mentioned level of independent variables resulted in the decrease in the cake weight. Manuel et al., (2008) reported that, substitution of chickpea flour with wheat flour in the level of 100, 50 and $0 \%$, had a profound effect on the weight of the baked layer cake from 200 to 183.5, 183.63 and $186.0 \mathrm{~g}$ respectively.

Thermal stability of the foam structure in starch cake batters was found to be highly dependent on the presence of unhydrolyzed or slightly hydrolyzed protein of high water solubility (Howard et al., 1968). 


\section{Effect of independent variables on specific volume}

The relationship between the independent variables and specific volume is mentioned by the equation and figure 2 below. Independent variables had significant effect on the specific volume of cake.

The adjustment of the second order to the specific volume indicated that barnyard millet flour was the variable that most influenced the specific volume of cake.

From the equation 2, it was observed that the binary system chickpea flour $\mathrm{x}$ barnyard millet flour and barnyard millet flour $\mathrm{x}$ maize flour exerted negative influence on the specific volume of cake.

Specific volume $=0.09+1.64 \mathrm{X}_{1}+3.07 \mathrm{X}_{2}+$ $1.64 \mathrm{X}_{3}-2.19 \mathrm{X}_{1} \mathrm{X}_{2}+0.96 \mathrm{X}_{1} \mathrm{X}_{3}-2.39 \mathrm{X}_{2} \mathrm{X}_{3}$ $+2.62 \mathrm{X}_{1} \mathrm{X}_{2} \mathrm{X}_{3}\left(\mathrm{R}^{2}=0.99 \ldots \ldots\right)$ ............................2

The cake prepared from the combination in the level of 56.25 to $70 \mathrm{~g}$ of chickpea flour, 20 to $30 \mathrm{~g}$ of millet flour and 6.25 to $21.5 \mathrm{~g}$ level of corn flour had highest specific volume (1.883). In addition, increasing or decreasing the level of corn flour was found to significantly affect the specific volume of cake.

Also, with increase in the level of extruded bean flour from 45 to $75 \%$, significant effect on specific volume and density of the cake were observed by Gomes et al., (2015).

Pulses had maximum total dietary fiber content compared to other food ingredients used (Bassinello et al., 2011; Carvalho et al., 2012), and according to Souza et al., (2013), the fibers were long chain polymers that impair the aeration process of the mass, since they are able to disrupt the structure of the dough and release the trapped air, responsible for aeration in bakery products such as breads and cakes.

\section{Effect of independent variables on cake density}

All the independent variables showed significant effect on the density of the cake.

The relationship between the overall acceptability and independent variables are described in the equation - 3 and figure 3 . All the variables exhibited as a special cubic effect and its interaction.

The adjustment of the second order to the cake density indicated that chickpea flour was the variable that most influenced the density of the cake.

Based on the equation - 3, it was observed that the binary system of chickpea flour $\mathrm{x}$ barnyard millet flour and tertiary system chickpea flour x barnyard millet flour x maize flour exerted negative influence on the density of the cake.

Cake density $=8.543 \mathrm{E}-003+0.61 \mathrm{X}_{1}+0.11$ $\mathrm{X}_{2}+0.62 \mathrm{X}_{3}+0.84 \mathrm{X}_{1} \mathrm{X}_{2}-0.19 \mathrm{X}_{1} \mathrm{X}_{3}+0.82$ $\mathrm{X}_{2} \mathrm{X}_{3}-1.43 \mathrm{X}_{1} \mathrm{X}_{2} \mathrm{X}_{3}\left(\mathrm{R}^{2}=0.99 \ldots \ldots\right)$ ............................. 3

The combination having the highest and lowest quantity of a pulse and corn flour respectively and medium quantity of barnyard millet flour brought about changes in the density of the cake.

Gomez (2009) reported that with increase in the level of chickpea flour, decrease in batter density was noted due to the less incorporation of air. It was also expected that lower batter density would result in higher cake volume, as was the case with the wheat and chickpea flour blended sponge cakes. 
Effect of independent variables on OAA score

Consumer acceptance is one of the most important criteria for any newly developed product. Since overall acceptability represents the consumer acceptance; it was also taken as one of the responses for the development of pulse based gluten free cake. The relationship between the overall acceptability and independent variables are shown in the equation - 4. Cakes containing highest levels of pulse flour and barnyard millet flour levels were rated high due to their overall acceptability by sensory evaluation.

Equation - 4 shows that up to a certain limit, the product acceptability changed due to interaction of barnyard millet flour with the other variables. All the variables were exhibited for special cubic effect (Equation- 4 and Fig. 4).

Table.1 Experiment for D-optimal design for gluten free cake mix

\begin{tabular}{|c|c|c|c|c|c|c|c|c|c|}
\hline \multirow[b]{2}{*}{$\begin{array}{c}\text { Sample } \\
\text { No. }\end{array}$} & \multicolumn{3}{|c|}{ Independent variables } & \multicolumn{6}{|c|}{ Dependent variables } \\
\hline & $\begin{array}{l}\text { CPF } \\
(\mathrm{g})\end{array}$ & $\begin{array}{c}\text { BMF } \\
(\mathrm{g})\end{array}$ & $\begin{array}{l}\text { CF } \\
(\mathrm{g})\end{array}$ & $\begin{array}{c}\text { Cake } \\
\text { weight } \\
(\mathrm{g})\end{array}$ & $\begin{array}{l}\text { Specific } \\
\text { volume } \\
\left(\mathrm{cm}^{3} / \mathrm{g}\right)\end{array}$ & $\begin{array}{c}\text { Cake } \\
\text { density } \\
\left(\mathrm{g} / \mathrm{cm}^{3}\right)\end{array}$ & $\begin{array}{l}\text { OAA } \\
\text { score }\end{array}$ & $\begin{array}{l}\text { Protein } \\
\mathrm{g} / 100 \mathrm{~g}\end{array}$ & $\begin{array}{l}\text { Fiber } \\
g / 100 g\end{array}$ \\
\hline $\mathrm{S}_{1}$ & 68.75 & 25.00 & 6.25 & 236.21 & 1.754 & 0.581 & 7.36 & 20.43 & 5.34 \\
\hline $\mathrm{S}_{2}$ & 60.00 & 30.00 & 10.00 & 238.04 & 1.812 & 0.555 & 7.39 & 18.06 & 5.43 \\
\hline $\mathrm{S}_{3}$ & 80.00 & 20.00 & 0.00 & 234.04 & 1.641 & 0.604 & 7.36 & 23.87 & 5.80 \\
\hline $\mathrm{S}_{4}$ & 56.25 & 22.50 & 21.25 & 235.41 & 1.753 & 0.587 & 7.22 & 15.9 & 4.67 \\
\hline $\mathrm{S}_{5}$ & 56.25 & 27.50 & 16.25 & 237.43 & 1.746 & 0.584 & 7.30 & 16.12 & 4.81 \\
\hline $\mathrm{S}_{6}$ & 50.00 & 20.00 & 30.00 & 235.01 & 1.637 & 0.618 & 7.15 & 14.79 & 3.94 \\
\hline $\mathrm{S}_{7}$ & 75.00 & 25.00 & 0.00 & 236.42 & 1.584 & 0.642 & 7.38 & 22.46 & 5.08 \\
\hline $\mathrm{S}_{8}$ & 70.00 & 30.00 & 0.00 & 238.44 & 1.639 & 0.626 & 7.50 & 21.08 & 4.66 \\
\hline $\mathrm{S}_{9}$ & 65.00 & 20.00 & 15.00 & 234.52 & 1.882 & 0.564 & 7.26 & 20.05 & 4.71 \\
\hline $\mathrm{S}_{10}$ & 70.00 & 30.00 & 0.00 & 238.12 & 1.631 & 0.628 & 7.42 & 21.29 & 4.48 \\
\hline $\mathrm{S}_{11}$ & 50.00 & 30.00 & 20.00 & 237.4 & 1.582 & 0.629 & 7.34 & 17.98 & 4.28 \\
\hline $\mathrm{S}_{12}$ & 50.00 & 20.00 & 30.00 & 234.9 & 1.641 & 0.613 & 7.15 & 17.98 & 4.08 \\
\hline
\end{tabular}

Table.2 Regression coefficients, $\mathrm{R}^{2}$, adjusted $\mathrm{R}^{2}$ and probability $(\mathrm{P})$ values for the gluten free cake mix

\begin{tabular}{|l|c|c|c|c|c|c|}
\hline \multirow{2}{*}{ Term model } & \multicolumn{6}{|c|}{ Response } \\
\cline { 2 - 7 } & $\begin{array}{c}\text { Cake } \\
\text { weight }(\mathrm{g})\end{array}$ & $\begin{array}{c}\text { Specific } \\
\text { volume } \\
\left(\mathrm{cm}^{3} / \mathrm{g}\right)\end{array}$ & $\begin{array}{c}\text { Cake density } \\
\left(\mathrm{g} / \mathrm{cm}^{3}\right)\end{array}$ & $\begin{array}{c}\text { OAA } \\
\text { score }\end{array}$ & $\begin{array}{c}\text { Protein } \\
\mathrm{g} / 100 \mathrm{~g}\end{array}$ & $\begin{array}{c}\text { Fiber } \\
\mathrm{g} / 100 \mathrm{~g}\end{array}$ \\
\hline $\mathrm{F}$ value & 96.45 & 1341.23 & 123.94 & 28.08 & 8.02 & 31.43 \\
\hline $\mathrm{P}>\mathrm{F}$ & $<0.0001^{*}$ & $<0.0001^{*}$ & $<0.0001^{*}$ & $0.0011^{*}$ & $0.0187^{*}$ & $0.008^{*}$ \\
\hline Mean & 236.33 & 1.69 & 0.60 & 7.32 & 19.17 & 4.77 \\
\hline $\mathrm{SD}$ & 0.21 & $3.515 \mathrm{E}-003$ & $3.390 \mathrm{E}-003$ & 0.027 & 1.28 & 0.13 \\
\hline $\mathrm{CV} \%$ & 0.089 & 0.21 & 0.56 & 0.37 & 6.67 & 2.79 \\
\hline $\mathrm{DF}$ & 11 & 11 & 11 & 11 & 11 & 11 \\
\hline $\mathrm{R}^{2}$ & 0.9914 & 0.9994 & 0.9933 & 0.9712 & 0.9058 & 0.9742 \\
\hline Adjusted R & 0.9812 & 0.9986 & 0.9853 & 0.9366 & 0.7928 & 0.9432 \\
\hline Predicted $\mathrm{R}^{2}$ & 0.8903 & 0.9947 & 0.9109 & 0.8618 & 0.1161 & 0.7388 \\
\hline Adeq. Precision & 26.168 & 111.146 & 32.666 & 15.10 & 8.253 & 17.678 \\
\hline
\end{tabular}

*significant at 0.05 level 
Fig.1 Response surface plot showing the effect of flours $\mathrm{X}, \mathrm{Y}$ and $\mathrm{Z}$ on cake weight DESIGN-EXPERT Plot Cake weight $\mathrm{X}_{1}=\mathrm{A}:$ Chickpea flour $x_{3}=\mathrm{C}:$ corn flour

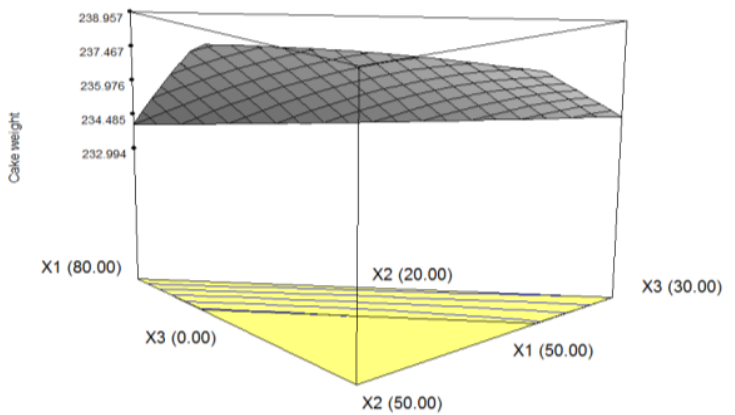

Fig.2 Response surface plot showing the effect of flours $\mathrm{X}, \mathrm{Y}$ and $\mathrm{Z}$ on specific volume DESIGN-EXPERT PIO Specific Volume
$\mathrm{X} 1=\mathrm{A}$. Chickpea $\mathrm{x}_{2}=\mathrm{B}$ : Barmyard millet flour $\mathrm{X}_{3}=\mathrm{C}:$ : Com flour

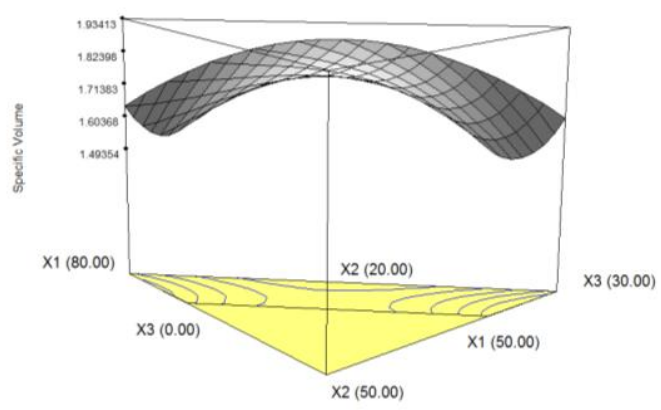

Fig.3 Response surface plot showing the effect of flours X, Y and Z on cake density DESIGN-EXPERT PIot Cake Density $X_{1}=A:$ Chickpea flour
$X_{2}=B$ $x_{2}=8$. Barnyard milet filo
$x_{3}=\mathrm{C}$ : Corm flour

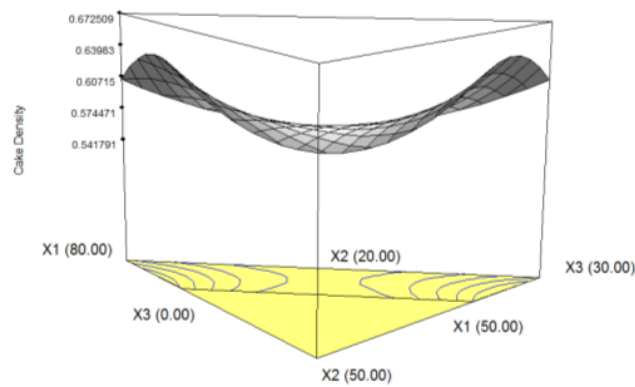

Fig.4 Response surface plot showing the effect of flours X, Y and Z on OAA score DESIGN-EXPERT Plot

$\mathrm{OAA}$ score
$\mathrm{X} 1=\mathrm{A}:$ Chickpea $\mathrm{X} 1=\mathrm{A}:$ : Chickpea flour
$\mathrm{X} 2=\mathrm{B}$ : Barnyard millet flour
$\mathrm{X} 3=\mathrm{C}$ : Corn flour

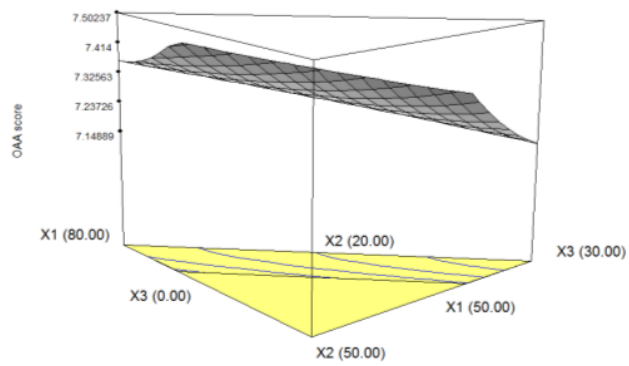


Fig.5 Response surface plot showing the effect of flours X, Y and Z on protein content DESIGN-EXPERT Plot Protein $X_{1}=A$ : Chickpea flour $\mathrm{X}_{2}=\mathrm{B}$ : Aarnyard milet flour

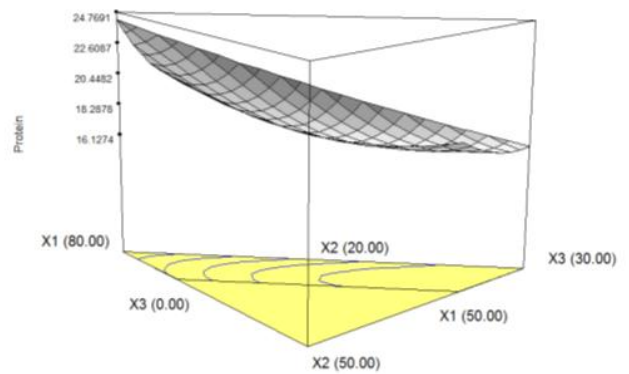

Fig.6 Response surface plot showing the effect of flours X, Y and Z on fiber content DESIGN-EXPERT PIOt Protein
$X_{1}=A:$ Chickpea flour $X_{2}=8$ : Barnyard millet flour $x_{2}=\mathrm{C}$ : : Com flour
$\mathrm{X}_{3}=\mathrm{C}$.

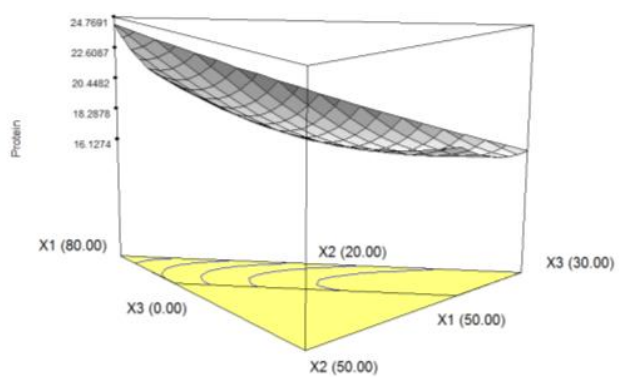

Overall acceptability $=0.12+7.36 \mathrm{X}_{1}+8.22$ $\mathrm{X}_{2}+7.15 \mathrm{X}_{3}+0.84 \mathrm{X}_{1} \mathrm{X}_{2}-0.028 \mathrm{X}_{1} \mathrm{X}_{3}$ $0.76 \mathrm{X}_{2} \mathrm{X}_{3}-0.25 \mathrm{X}_{1} \mathrm{X}_{2} \mathrm{X}_{3}\left(\mathrm{R}^{2}=0.97 \ldots \ldots\right)$ 4

According to the equation 4, it can be observed that the binary system chickpea flour x maize flour and barnyard millet flour $\mathrm{x}$ corn flour exerted negative influence decreasing the overall acceptability, whereas the binary system of chickpea flour $x$ barnyard millet flour showed an antagonistic effect and increased the overall acceptability score of the cake.

All formulation of cakes had overall acceptability scores ranging from 7 (liked moderately) to 8 (like very much). The combination of below the level of 50, 20 and $20 \mathrm{~g}$ of chickpea, barnyard and corn flour respectively had low overall acceptability scores as was also absent with increasing level of corn flour and above medium level of barnyard millet flour. Gomes et al., (2015) reported that all the extruded bean flour added cakes had an acceptability score of above six. The property of legumes to promote greater hardness of cakes was also reported by Gularte et al., (2011) who found a significant increase in hardness of cakes prepared with beans, chickpeas and peas.

\section{Effect of independent variables on protein content}

The interaction between the independent variables and protein responses were significantly $(\mathrm{P}<0.05)$ different and it is shown in the equation - 5 and figure 5 . The variable interacted with its protein value in the special cubic model.

The adjustment of the second order to the protein indicated that chickpea flour was the variable that most influenced the protein content of the cake. The interaction between barnyard millet flour and maize flour was not significant for the protein content of the cake. 
According to equation - 5, it can be observed that the binary and tertiary system of one factor with other factor and interaction with other two factors exerted negative influence increasing the protein content.

Protein $=78.50+24.24 \mathrm{X}_{1}+33.44 \mathrm{X}_{2}+$ $16.19 \mathrm{X}_{3}-29.32 \mathrm{X}_{1} \mathrm{X}_{2}-1.81 \mathrm{X}_{1} \mathrm{X}_{3}-19.50$ $\mathrm{X}_{2} \mathrm{X}_{3}-42.45 \mathrm{X}_{1} \mathrm{X}_{2} \mathrm{X}_{3}\left(\mathrm{R}^{2}=0.97 \ldots \ldots\right)$ .........................5

The developed gluten free cake combination had protein levels ranging from 14.79 to $23.87 \mathrm{~g} / 100 \mathrm{~g}$. Increasing the level of chickpea flour was found to have a significant influence the protein content of the cake as also with increasing the level of barnyard millet flour. In addition to the increase in protein content of the prepared cake samples from the investigated cake mix, the added advantage was that the protein was gluten free and confers health benefits to consumers particularly the celiac patients as a protein source which is needed for physiological functioning (Ugwuona et al., 2012).

\section{Effect of independent variables on fiber}

Independent variables such as chickpea flour, barnyard millet flour and maize flour had profound interaction in terms of the fiber content of the cake as show in equation - 6 and figure 6. The suitable interaction was made for special cubic model.

Fiber $=3.35+5.82 X_{1}+5.91 X_{2}+4.02 X_{3}-$ $5.63 \mathrm{X}_{1} \mathrm{X}_{2}-0.70 \mathrm{X}_{1} \mathrm{X}_{3}-1.83 \mathrm{X}_{2} \mathrm{X}_{3}+26.96$ $\mathrm{X}_{1} \mathrm{X}_{2} \mathrm{X}_{3}\left(\mathrm{R}^{2}=0.97 \ldots \ldots\right)$ .......6

The adjustment of the second order to the fiber content indicated that all the independent variables mostly influenced the gluten free cake. The interactions of one variable with other variable were significant for the cake fiber content. The tertiary system of the chickpea flour, barnyard millet flour and corn flour exerted positive influence on the fiber content increasing the fiber content of the product.

Decreasing the level of $\mathrm{CPF}, \mathrm{BF}$ and $\mathrm{CF}$ was found to highly influence the changes in the fiber content of the product. The fiber content ranged from 4.08 to $5.80 \mathrm{~g} / 100 \mathrm{~g}$ of developed cake. Morkos et al., (2013) reported that with increasing level of the chickpea flour in development of gluten free butter cake, there was concomitant increase the level of crude fiber content up to $9.95 \mathrm{~g} / 100 \mathrm{~g}$. The same results were recorded in other studies by Saura-Calixa et al., (2000) and Rosin et al., (2002). Dietary fiber in these cake preparations is important due to its functional effect on the gut. For instance, viscous fiber containing foods may elicit low postprandial glycemic responses due to delayed glucose absorbance (Tover et al., 1992).

\section{Optimization}

The numerical optimization technique has been implemented to desire the best optimum combination for development of gluten free cake. It is one of the best techniques which result in radically reducing the amount of time and effort required for the investigation of multifactor and multiple-response systems (Kathiravan et al., 2015). To optimize the raw materials, the response surface models for independent variables were fixed in the level for maximum in chickpea flour, optimum level for barnyard millet flour and minimum level for corn flour with dependent variables, which were fixed in maximum level of cake weight, specific volume, OAA score and minimum level of weight loss and cake density. From the analysis of optimization the independent variable levels were as $64.85 \mathrm{~g}$ of chickpea flour, $30 \mathrm{~g}$ of barnyard millet flour and $5.15 \mathrm{~g}$ of corn flour. The cake mix was prepared using the optimized composition and 
was verified for the predicted values and the actual values for the responses.

In conclusion, the present study demonstrated that gluten free cake mix could be optimized by the experiments of D - Optimal Design in RSM. According to the RSM results and the numerical optimization technique, the $\mathrm{CPF}$ $64.85 \mathrm{~g}$; BF $30 \mathrm{~g}$ and CF $5.15 \mathrm{~g}$ can be recommended as the best optimum combination of the cake mix. In this optimized combination, the cake had a weight $238.23 \mathrm{~g}$, specific volume $-1.773 \mathrm{~cm} 3 / \mathrm{g}$, cake density - $0.571 \mathrm{~g} / \mathrm{cm} 3$, overall acceptability score -7.42 , protein $-19.11 \mathrm{~g}$ and fiber -5.20 $\mathrm{g}$ per $100 \mathrm{~g}$. From the technological, nutritional and sensory perspectives, the complete utilization of chickpea and barnyard millet flour is viable and recommended in the food industry for the development protein rich gluten free cake, with the objective of addressing the health concerns, especially for celiac disease with affordable economic value to pulse utilization and its byproducts and diversification in the bakery market.

\section{Acknowledgement}

This research was supported by Saskatchewan Pulse Crop Development Board, Canada.

\section{References}

AACC, (2000). Approved methods of the American Association of Cereal chemists. $9^{\text {th }}$ edn. AACC. St. Paul. Minessota, USA.

Bassinello, P.Z., Freitas, D.G.C., Ascheri, J.L.R., Takeiti, C.Y., Carvalho, R.N., Koakuzu, S.N., and Carvalho, A.V. (2011). Characterization of cookies formulated with rice and black bean extruded flours. Procedia Food Science, 1(1), 1645-1652. http://dx.doi.org/ 10.1016/j. profoo.2011.09.243.

Bezerra, M., Santelli, R., Oliveira, E., Villar,
L., Escaleira, L. (2008). Response Surface Methodology (RSM) as a Tool for Optimization in Analytical Chemistry. Talanta, 76, 965-977.

Boye, J., Zare, F. and Pletch, A. (2010). Pulse proteins: processing, characterization, functional properties and applications in food and feed. Food Research International, 43, 414-431.

Carvalho, A.V., Rios, A.O., Bassinello, P.Z. and Ferreira, T.F. (2012), Effect of the thermoplastic extrusion parameters on the technological properties of precooked flours prepared with rice and beans, Brazilian Journal of Food Technology, 15(4), 343-342. http://dx.doi.org/10.1590/S1981-672320 12005000029

Dimitrios, S., Eleousa M. and Georgios, D. (2006). Effect of durum flour enrichment with chickpea flour on the characteristics of dough and lasagna. Journal of the Science of Food and Agriculture, 86(12), 1938-1944.

Duranti, M. (2006). Grain legume proteins and nutraceutical properties. Fitoterapia 77, 67-82.

El-Adawy, T.A. (2002). Nutritional composition and antinutritional factors of chickpeas (Cicer arietinum L.) undergoing different cooking methods and germination. Plant Foods Hum Nutr, 57(1), 83-97.

Gomes, L.O.F., Santiago, R.A.C. Carvalho, A.V., et al., (2015). Application of extruded broken bean flour for formulation of gluten-free cake blends. Food Sci. Technol, Campinas, 35(2), 307-313.

Gomez, M., Oliete B., Rosell, C.M., Valent, P. and Fernandez, E. (2008). Studies on cake quality made of wheat - chickpea flour blends, LWT - Food Science and Technology, 41, 1701-709.

Gularte, M.A., Gomez, M. and Rosell, C.M. (2011). Impact of legume flours on 
quality and in vitro digestibility of starch and protein from gluten-free cakes. Food Bioprocess Technology, 31, 195-202.

Hadimani, N.A. and Malleshi, N.G. (1993). Studies on miling, physico-chemical properties, nutrient composition and dietary fibre content of millets. Journal of Food Science and Technology, 30(1), 17-29.

Howard, N.B., Hughes, D.H. and Strobel, R.G.K. (1968). Function of starch granule in the formation of layer cake structure. Cereal chem. 45, 329-338.

Josephine, S.N., Aruna Singh and Baskar, G. (2014). Osmotic Dehydration of Fruits An Integrated Approach, International Journal of Food and Nutritional Sciences, 3(3), 18-23.

Karuppasamy. P., Malathi. D., Banumathi. P., Varadharaju. N. and Seetharaman, K. (2013). Evaluation of quality characteristics of bread from kodo, little and foxtail millets. International Journal of Food and Nutritional Sciences, 2(2), 35-39.

Kasarda, D.D. (2001). Grains in relation to celiac disease. Cereal Foods World, 46, 209-210.

Kathiravan, T., Nadanasabapathi, S. and Kumar, R. (2015). Pigments and antioxidant activity of optimized Readyto-Drink (RTD) Beetroot (Beta vulgaris L.) - passion fruit (Passiflora edulis var. flavicarpa) juice blend, Croat. J. Food Sci. Technol. 7(1), 9-21.

Khan, E.A., Aslam, M., Ahmad, H.K., Himayatullah, Khan, M.A, and Hussain, A. (2010). Effect of row spacing and seeding rates on growth, yield and yield components of chickpea. Sarhad $J$. Agric., 26(2), 201-211.

Kim, J.Y., Jang, K.C., Park, BR. et al., (2011). Physicochemical and antioxidative properties of selected barnyard millet (Echinochloa utilis) species in Korea. Food science and biotechnology, 20(2), 461-469.

Naveena. N. and Bhaskarachary, K. (2013). Effects of soaking and germination of total and individual polyphenols content in the commonly consumed millets and legumes in India. International Journal of Food and Nutritional Sciences, 2(3), 12-19.

Nithiya, D.J., Basco, K.A, Saravanan, M., Mohan, R.J. and Alagusundaram, K. (2016). Optimization of process variables for extrusion of Rice-Bengal gram blends. Indian Journal of Scientific and Industrial Research, 75, 108-114

Pradeep, S.R., Malleshi, N.G. and Guha, M. (2011). Germinated Millets and Legumes as Source of Gamma Aminobutyric Acid. World Appl. Sci. J., 14(1), 108-113.

Rosin, M., Lajolo, M., and Menezes, W. (2002). Measurement and characterization of dietary starches. $J$. Food Composition and Analysis, 15, 367-377.

Sabanis, D., Makri, E. and Doxastakis, G. (2006). Effect of durum flour enrichment with chickpea flour on the characteristics of dough and lasagne. $J$. Sci. Food Agr, 86, 1938-1944.

Sadaf, J., Sarfara K.M., Saeeda, R., Hameed, A. and Waseem, K. (2016). Formulation of Gluten-Free Baked Products for Coeliac Patients: A Review of Contemporary Methodologies and Quality Improving Factors. AmericanEurasian J. Agric. and Environ. Sci., 16 (4), 826-835.

Saura, C.F., Garcia, A.A., Goni, I. and Bravo, L. (2000). In vitro determination of the indigestible fraction in foods: an alternative to dietary fibre analysis. $J$. Agric. and Food Chem., 48, 3342-334.

Schalk, K., Lexhaller, B., Koehler, P. and Scherf, K.A. (2017). Isolation and 
characterization of gluten protein types from wheat, rye, barley and oats for use as reference materials. PLoS ONE, 12(2), e0172819.

Shogren, R.L., Mohamed, A.A. and Carriere, C.J. (2003). Sensory Analysis of Whole Wheat/Soy Flour Breads. Journal of Food Science, 68(6), 2141-2145.

Sin, H.N., Yusof, S., Hamid, N.S.A. and Rahman, R.A. (2006). Optimization of hot water extraction for sapodilla juice using response surface methodology, J. Food Engi. 74, 352-358.

Souza, T.A.C., Soares, M.S., Jr., Campos, M.R.H., et al., (2013). Gluten free cakes made with broken rice and cassava peel, Semina, 34, 717-728.

Tovar, J., Granfeldt, Y. and Bjorck, I.M. (1992). Effect of processing on blood glucose and insulin responses to starch in legumes. J. Agric. and Food Chem., 40, 1846-1851.

Ugwuona, F.U., Ogara, J.I. and Awogbenja, M.D. (2012). Chemical and sensory quality of cakes formulated with wheat, soybean and cassava flours. Indian Journal of Life Science. 1(2), 1-6.

Mona, M.M, Halaby, S., Raafat, N.S. and
Hanna, M.M. (2013) Microbiological Analysis of Fortified Cakes with Peanut and Chickpea to Celiac Patients, $J$. Appl. Sci. Res., 9(4), 3263-3270.

Valentine, S.P.A., Andrew, P. and Senol, I. (2010). The advantage of using extrusion processing for increasing dietary fibre level in gluten-free products. Food Chemistry, 121(1), 156164.

Veena, S., Bharati, V.C., Rama, K.N. and Shanthakumar, G. (2005). PhysicoChemical and Nutritional studies in Barnyard Millet. Karnataka J. Agric. Sci., 18(1), 101-105.

Wang, J., Rosell, C.M. and Barber, C. (2002). Effect of the addition of different fibers on wheat dough performance and bread quality. Food Chemistry, 79, 221-226.

Wood, J.A. and Grusak, M.A. (2007). Nutritional value of chickpea. In: Chickpea Breeding and Management, (edited by Yadav, S.S., Redden, R., Chen, W. and Sharma, B. editors). Pp. 101-142. Wallingford: CAB International.

\section{How to cite this article:}

Thirukkumar Subramani, Hemalatha Ganapathy and Senthamaraiselvi Lakshmanan. 2017. Standardization of Gluten Free Chickpea Flour Based Cake Mix by Using Response Surface Methodology. Int.J.Curr.Microbiol.App.Sci. 6(8): 963-974. doi: https://doi.org/10.20546/ijcmas.2017.608.118 